\title{
KNOWLEDGE ONESSENTIAL NEWBORN CARE AMONG POST NATAL MOTHERS
}

\section{Sr. Moncy Francis*|Dr. Bimla Rani**}

${ }^{*}$ Research Scholar, Himalayan University, Itanagar in Arunachal Pradesh, India. \& Assistant Professor, St. John's College of Nursing, Kattappana, Kerala.

**Research Supervisor, Himalayan University, Itanagar in Arunachal Pradesh, India. DOI: http://doi.org/10.47211/idcij.2021.v08i03.004

\section{ABSTRACT}

The birth of the baby is one of the wondrous moments in their life. A newborn is a continuum of foetal life and an important transient time to adopt extrauterine life. Essential Newborn care refers to the care provided by the mother or caregiver regarding breastfeeding, care o cord and eyes, maintaining body temperature, immunization, and controlling the infection. Objectives: To assess the knowledge level of postnatal mothers regarding Essential Newborn Care. Materials and methods: A non-experimental descriptive study was conducted in a selected hospital, Idukki to assess the knowledge of post-natal mothers regarding essential newborn care. A total of 50 post-natal mothers were selected with a non-probability con venience sampling technique. A quantitative research approach was used in this study. A self-structured questionnaire was used to gather the data, and appropriate statistics were performed to analyse the data. Results: The data results revealed that $50 \%$ of samples are in the age group of 19-27 yrs. and 50\% were 28-36years of age. The majority of the samples (72\%) were Christians. Half of the samples (58\%) were graduates and $22 \%$ were postgraduates. Concerning the level of knowledge, $10 \%$ of them had poor, $60 \%$ had average and $22 \%$ had good knowledge regarding essential newborn care.

Keywords: EssentialNewborn care, knowledge, post-natal mothers

\section{ABOUT AUTHORS:}

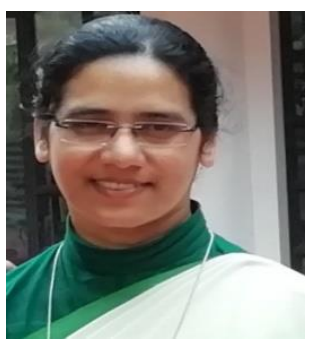

Author Sr. MoncyFrancis is a ResearchScholar at Himalayan University, Itanagar in Arunachal Pradesh, India.

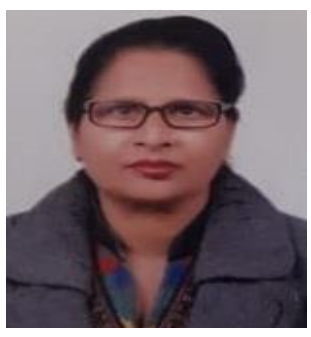

Author Dr. Bimla Rani is a Research Supervisor at Himalayan University in Itanagar, Arunachal Pradesh, India. She has presented papers in various conferences and also has many publications to her name. 


\section{INTRODUCTION}

"Birth" means the bestowing of some form of life by the nature to this world. Being born is the pur est virtue that can be held by a living being as after that one is exposed to life, where one can breathe, feel, have emotions, it's in this world that this one is exposed to all such virtues. This is a state in which we consider the achievement of a new form of life.

The first week of life is the most crucial period in an infant. The newborn care procedures begin imme diately after birth. In clinical settings, various routine procedures can be administered, neglected, de layed, or even refused. Each parent has the right to get necessary information regardingevery procedure and they have to learn about to perform successfully to their child. Their attention should be a focus on immediate and exclusive breastfeeding, drying, warming, weighing, and measuring of baby, immunization, perio dic heal th visits, etc.

All newborns have certain needs that must be met for them to thrive and take their place in society. There are nine universal needs for a newborn. i.e., Clear airway, establishing respiration, warmth, protection from infection, nourishment and fluids, identification and observation, love -parent attachment. "A healthy child is the nation's pride," remarked WHO. Every newborn has the right to get possible conditions for the ir growth and development because they are the asset for the nation's development.

Neonatal care is a fundamental component in reducing the child mortality rate. Newborns are the powerless bunch and therefore theyrequire more consideration and care (Yisak, H.2020). More than $40 \%$ of ne on atal death can be prevented by giving propercare at the time of delivery, initiated by the skilled birth atten dant, emergency obstetric care, and immediate care of the newborn at the time of delivery. The other key interventions to prevent ne onatal mortality rate are kangaroo mother care, prevention, and man ageme nt of neonatal sepsis and jaundice, birth asphyxia (Pankaj K, 2021)

Essential newborncare is recommended by the World Health Organization, designed to imp rove the health quality of newborns through care during preconception, pregnancy, and post-natal periods. Globally neonatal mortality remains high in underdeveloped countries. In 2018, approximately 2.5 million die in their first month of life which means 7000 per day. Even in developing countries, the burden of neonatal death is still high. WHO stated that "a customary practice that reducesneonatal mortality and morbidity has been iden tified as indispensable and they include essential newborn care (Abebe. $\mathbf{H}, \mathbf{2 0 2 1}$ )

\section{NEED FOR THE STUDY}

The first month of life is the most vulnerable period. This makes focus on newborn care is more essential and critical. The global cause of death of an infant is preterm birth complications, meningitis, me asles, malaria, congenital problems, diarrhoea, and pneumonia. In 2019, 2.4 million children die in theirfirst month of life approximately 6700 newborns every day. Neonatal death rates declined from 37 per 1000 live birth to 17 deaths per 1000 livebirth in 2019. (UNICEF, 2020).

In India, the current infant mortality rate in 2021 is 28.77 deathsper 1000 live birth. In 2020, it was 29.848 (India); 6.89 (Sree Lanka); 18.39 (Philippians); 57.19 (Pakistan). The birth rate in the world is 17.87 per 1000 people in 2021 and 18.07 per 1000 people in 2020. The number of births in India is 24,067 in the year 2020 (Macrotrend, 2021). Kerala's infant mortality rate in 2015 was 6 deaths per 1000 live birth and it was 7 in 2020. In the Idukki district, it is 16: 9: 25 in rural/semi-urban and urban respectively.

Based on the above statistics the researcher felt the need to reduce the morbidity and mortality rate by imparting the knowledge on essential newborn care among postnatal mothers. As most of the deaths in a newborn occur during the first week after the birth, it is important to provide adequate knowledge on newborn care to post-natal mothers. Therefore, this study was aimed at assessing the knowledge of post-natal mothers on essential newborn care.

STATEMENT OF THE PROBLEM:

"A study to assess the knowledge on Essential Newborn Care among postnatal mothers admitted in a selected hospital, Idukki Dt, Kerala."

\section{OBJECTIVES OF THE STUDY}

- To assess the level of knowledge of post-natal mothers regarding essential newborncare

- To determine the association between knowledge of mothers with selected demographic variables 


\section{ARTICLES}

\section{OPERATION DEFINITION:}

Newborn: In this study, it refers to babiesaged from 0-28 days.

Knowledge on essential newborn care: In this study, it refers to the awareness of the post-natal mothers on thermoregulation, early breastfeeding, umbilical cord care, eye care, prevention of infection, and immunization.

Post-natal mother: In this study, it refers to a mother who has given birth to her first baby and whose age of the baby is in between 0-28 days

\section{MATERIALS AND METHODS}

- Research Design: in this study, a Descriptive Research design was used.

- Research Approach: In this study, A quantitative research approach was considered

- Setting: The study was conducted in the post-natal ward of St. John's Hospital, Kattappana. It is a 300 beddedhospital having 19 departments. The post-natal ward is having a capacity of 35 beds which is functioning under 3 Gynaecologists. Annually around 700 post mothers are getting admitted and monthly it is around 50.

- Sample size: 50 post-natal mothers with an age group of 19-36years were selected.

- Sampling technique: In this study, Convenience samplingtechnique were used

Data collection tool:

- Part I: Demographic data which consists of age, religion, education, occupation, family income, type of family, and area of living

- Part II: Self-structured questionnaire which consists of 20 multiple choice questions to assess the level of knowledge regarding essential newborncare.

Data analysis: For data analysis, descriptive and inferential statistics were used.

RESULTS:

Part I: Demographic data

Table 1: Distribution of samples based on demographic variables

\begin{tabular}{|c|c|c|c|c|c|c|c|}
\hline SL No & Variables & $f$ & $\%$ & SL No & Variables & $f$ & $\%$ \\
\hline 1 & $\begin{array}{l}\text { Age } \\
19-27 \\
28-36\end{array}$ & $\begin{array}{l}25 \\
25\end{array}$ & $\begin{array}{l}50 \\
50\end{array}$ & 5 & $\begin{array}{l}\text { Family income } \\
<15000 \\
15000-30000 \\
>30000\end{array}$ & $\begin{array}{l}18 \\
16 \\
16\end{array}$ & $\begin{array}{l}36 \\
32 \\
32\end{array}$ \\
\hline 2 & $\begin{array}{l}\text { Religion } \\
\text { Christian } \\
\text { Hindu } \\
\text { Muslim }\end{array}$ & $\begin{array}{l}36 \\
12 \\
2\end{array}$ & $\begin{array}{l}72 \\
24 \\
4\end{array}$ & 6 & $\begin{array}{l}\text { Type of family } \\
\text { Nuclear } \\
\text { Joint }\end{array}$ & $\begin{array}{l}28 \\
22\end{array}$ & $\begin{array}{l}56 \\
44\end{array}$ \\
\hline 3 & $\begin{array}{l}\text { Education } \\
\text { School-level } \\
\text { Graduates } \\
\text { Postgraduates }\end{array}$ & $\begin{array}{l}10 \\
29 \\
11\end{array}$ & $\begin{array}{l}20 \\
58 \\
22\end{array}$ & 7 & $\begin{array}{l}\text { Area of living } \\
\text { Rural } \\
\text { Urban }\end{array}$ & $\begin{array}{l}38 \\
12\end{array}$ & $\begin{array}{l}76 \\
24\end{array}$ \\
\hline 4 & $\begin{array}{l}\text { Occupation } \\
\text { Housewife } \\
\text { Labourer } \\
\text { Govt/pvt } \\
\text { employee }\end{array}$ & $\begin{array}{l}31 \\
6 \\
13\end{array}$ & $\begin{array}{l}62 \\
12 \\
26\end{array}$ & & & & \\
\hline
\end{tabular}




\section{ARTICLES}

Part II: level of knowledge on essential newborn care

Figure 1: level of knowledge on essential newborn care

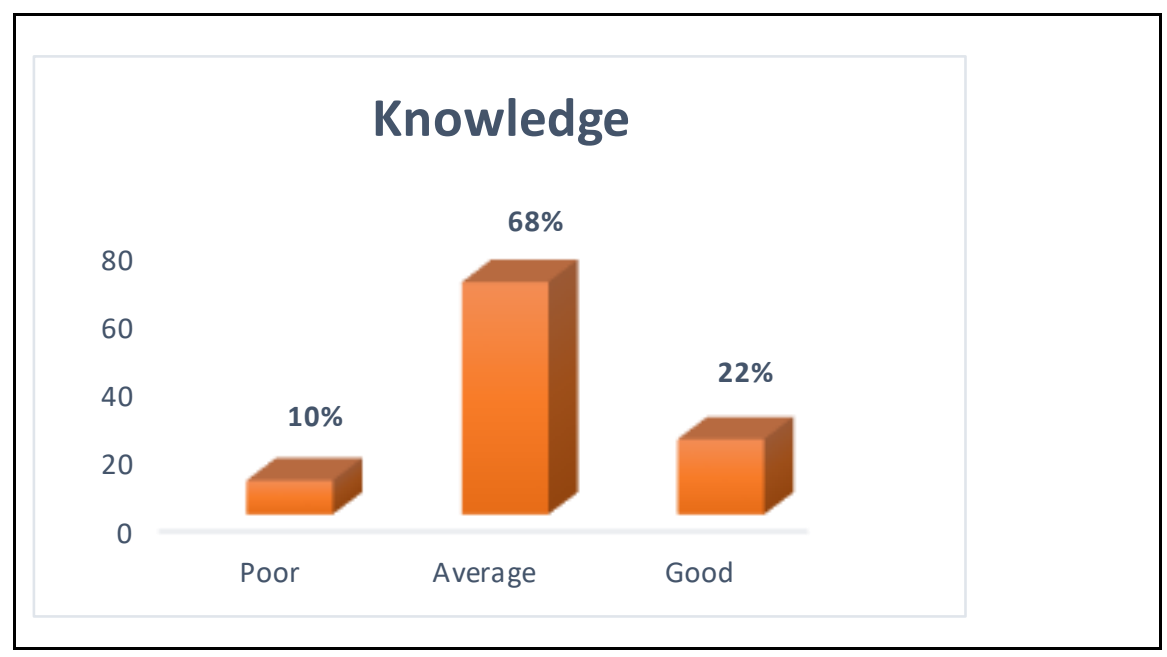

Figure I show that $10 \%$ of the samples had poor, $60 \%$ had average and $22 \%$ had good knowledge regarding essential newborncare.

Part III-Association of the level of knowledge and demographic variables

Table 2: Association of the level of knowledge and demographic variables

\begin{tabular}{|l|l|l|l|l|l|}
\hline SL No & variables & Chi-square & df & $\begin{array}{l}\text { p- } \\
\text { value }\end{array}$ & Level of significance \\
\hline 1 & Age & 1.46 & 2 & 5.99 & Non-significant \\
\hline 2 & Religion & 12.59 & 4 & 9.49 & Significant \\
\hline 3 & Education & 17.80 & 4 & 9.49 & Significant \\
\hline 4 & Occupation & 18.89 & 4 & 9.49 & Significant \\
\hline 5 & Family income & 6.41 & 4 & 9.49 & Significant \\
\hline 6 & Type of family & 3.27 & 2 & 5.99 & Non-significant \\
\hline 7 & Area of living & 3.55 & 2 & 5.99 & Non-significant \\
\hline
\end{tabular}

$\mathbf{P}=\mathbf{0 . 0 5}$

Data in this table shows that there was a significant association between the knowledge score of staff nurses with religion, education, occupation, and family income. There was no association betwe en the kn owledge score of age, type of family, and area of living. 


\section{DISCUSSION}

\section{Part I: Distribution of samples based on demographic data}

Demographic variables selected for this study were age, education, occupation, family income, type of family, and area of living. $50 \%$ of samples belong to both age group (19-27, 28-36). The majority of the samples (72\%) were Christians whereas $24 \%$ were Hindus. $58 \%$ of the samples were graduates and $22 \%$ were postgraduates, and $20 \%$ were studied at the school level. Most of them (62\%) were housewives. Nearly half of the $\mathrm{m}(36 \%)$ had a family income of $<15000$ per month whereas $32 \%$ had $>35,000$ per month. Above half ( $56 \%$ ) belongs to nuclear family and rest of them (44\%) belong to joint family. Most of the samples (76\%) were residing in r u ral areas.

\section{Part II: level of knowledge on essential newborn care}

The findings of the present study showed that $10 \%$ of them had poor, $68 \%$ had average and $22 \%$ had a good level of knowledge regarding essential newborn care. These findings were supported by other studies: $37 \%$ had a good level of knowledge, $81.2 \%$ of samples had good knowledge and $18.8 \%$ had poor knowledge (Yisak $\mathrm{H}, 2020$ ). A supportive study reported that the mean knowledge in primigravida mothers was 67.2 that indicate they were having moderately adequate knowledge (Vinod V, 2014). Another study showed that among the total 60 samples,16(26.7\%) had inade quate knowledge,30(50\%) had moderatel $y$ adequate knowledge and $14(23.3 \%)$ mothers had adequate

knowledge. (Thenmozhi, $P, 2017$ ). In the present study, $86 \%$ of mothers known about themodes of thermoregu lation, $94 \%$ of them knew of the frequency of breast feeding, $68 \%$ of mothers knew that the umbilical cord should be left uncovered and clean, $82 \%$ of them were aware of birth vaccines, $84 \%$ were aware of prevention of infections. A supportive study showed that nearly half of the samples were practicing exclusive breastfeeding and more than half of the mothers were aware of the initiation of breastfeeding within one hour of birth and Exclusive breastfeeding was practiced by nearly half (47\%) of the mothers. (Pankaj, KP, 2021).

\section{Part III: Association between the level of knowledge and demographic variables}

The present study revealed that there was a significant association between knowledge on newborn care with selected demographic variables such as religion, education, occupation, and family inco me. This study was supported by another study that there is an association of knowledge with occupation ( $p=0.027)$ (Bhattarai M, 2021). In the present study, there was no significant association between other variables like age, type of family, and area of living. Another study supported that there was no association of knowledge level and age, area of living, and type of family (Vinod V, 2014). In a study, it was noticed that there was a significant association of knowledge level with occupation and education. (Berhan D et.al. 2018). A study showed that mothers with no education had less significant knowledge scores compared to those who had higher education. (Memon et al, 2019).

\section{CONCLUSION}

The present study was conducted to assess the knowledge of post-natal mothers on Essential Ne wborn care and to find out the association of knowledge with the selected variables. After meeting the inclusion criteria 50 samples were selected with convenience sampling technique. By using a self-structured question naire, the knowledge of the post-natal mothers collected and the data were coded and analyzed. The study concluded with the findings that the majority $34(68 \%)$ of the samples had average knowledge, $1(22 \%)$ had good knowledge and 5(10\%) had poor knowledge regarding Essential Newborncare. So, the researcher pla nned to develop an information booklet regarding the needed care for the newborn and thereby improve the optimum growth and reduce infant mortality and morbidity rate.

\section{RECOMMENDATIONS}

- A structured teaching program could have been implicated to improve their knowledge on Essential newborn care

- Health awareness program can be performed in a community setting

- Periodic training regarding Essential newborn care can be arranged in clinical settings especially in paediatric and Gynaecology departments 


\section{ARTICLES}

\section{REFERENCES}

1. Amolo L. (2017). Knowledge of postnatal mothers on essential newborn care practicesat the Kenyatta National Hospital: a cross-sectional study. Pan African Medical Journal-ISSN:19378688. http://www.panafrican-med-journal.com/content/article/28/97/full.

2. Berhan D et.al. (2018). Level of Knowledge and Associated Factors of Postnatal Mothers towards Essential Newborn Care Practices at Governmental Health Centres in Addis Ababa, Ethiopia. Hin dawi Advances in Public Health Volume 2018, Article ID 8921818, 1-10. https://doi.org/10.1155/2018/8921818

3. Bhattarai, Met al. (2021). Knowledge and Practice on neonatal care among postnatal mothers in a selected teaching hospital, Kaski Dt, Nepal. International Journal of Social Sciences and Management 8(1).279-284. DOI:10.3126/rjssm. v8i1:33570.

4. Macrotrends/net/countries/IND/India/infant mortality rate, 202.

5. Memon et al. (2019). Knowledge, attitude, and practice among mothers about newborn care in Sindh, Pakistan. BMC Pregnancy and Childbirth .19:329.1-9. https://doi.org/10.1186/s12884-019-2479-0

6. Thenmozhi, P (2017). Knowledge and practice on essential Newborn care among primipara mothers. Saudi Journal of Medical and PharmaceuticalSciences. Scholars Middle East Publishers ISSN 2413 4910

7. United Nations inter-agency, group for child mortality estimation levels and trends in child mor tality report 2020: UNICEF, New York;2020. Data.unicef.org/topic/maternal health/newborncare.

8. Vinod, V (2014). A descriptive study on newborn care. Asian Journal of nursing education and research 4(4). www.anvpublication.org.ISSN-2231-1149

9. Yisak H (2020). Knowledge, attitude, and practice of newborn care among post-natal mothers at Debre Tabor General Hospital South Gonder, Ethiopia, 2018, Glob J of ped and Ne on atal car.2 (5), 2020.GJPNC.MS.ID.000543. 